\title{
Application of Phytotoxkit microbiotest for hazard assessment of bottom sediments in the eutrophic dam reservoir
}

\author{
Adriana Trojanowska \\ University of Wroclaw, Department of Applied Geology and Geoecology, Cybulskiego 30, 50-205 Wrocław, Poland; \\ e-mail: adriana.trojanowska@ing.uni.wroc.pl
}

\begin{abstract}
The aim of this study was to estimate ecotoxicity of the sediments from the shallow, eutrophic dam reservoir - Sulejowski. Research was carried out using Phytotoxkit microbiotests, which measure inhibition of seeds germination and roots growth retardation of the three species of plants (dicotyl Lepidium sativum, Sinapis alba, monocotyl Sorgum saccharatum). Tested plants gave different response to sediment samples, with decreasing sensitivity gradient: L. sativum, S. saccharatum, S. alba. The relationship of phytotoxicity of sediments with its water content was recorded $(r=0.63, p<0.05)$. The results obtained showed spatial diversification along the reservoir, with the highest values in its opposite ends of the upper and lower parts (up to 87\%), which are separated by a central area with the lowest toxicity (up to 45\%). Possible reasons and implications of bottom sediments phytotoxicity are discussed.
\end{abstract}

Key words: toxicity, Phytotoxkit, bottom sediements, dam reservoirs.

\section{Introduction}

Dam reservoirs constructed on lowland rivers suffer numerous environmental and water quality problems. Tributaries usually deliver large loads of organic and inorganic pollutants, which undergo enhanced sedimentation along the reservoir basin due to lowered water flow velocity (Straškraba and Tundisi 1999). Sediments act as sinks for different type of pollutants (trace metals, WWA, pesticides etc.), which achieve there much more higher concentrations than in water and may be chemically transsformad and deeposited on the bottom or liberated to overlying water under certain conditions and being biologically available (Bojakowska and Gliwicz 2003). Moreover, some toxic substances may be produced in the reservoir in situ, such as cyanobacterial toxins produced during green-algae blooming in eutrophic reservoirs (Zalewski et al. 2000; Majsterek et al. 2004), which may remain active in the organic sediments for a long time and can be a secondary source of contamination of water (Morris et al. 2000; Latif and Licek 2004; Zakaria et al. 2007). Therefore they might be potentially dangerous especially in dam reservoirs gathering water for drinking purposes, agricultural irrigation or being recreationally used.
Microbiotests usefulness in the standard monitoring of aquatic environments was already proved as an sensitive and low-cost routine screening tests of environmental samples quality (Latif and Licek 2004; Kaza et al. 2007; Wadhia et al. 2007; Mankiewicz-Boczek et al. 2008) even being recommended as a tool in Water Framework Directive Implementation (Wadhia and Thompson 2007). Chemical and physical analyses detect hazard substances present in environment, but except of information on the amount of single contaminants does not deliver signals on environmental stress to organisms, which is especially important if synergistic or antagonistic interactions of mixture of pollutants appear (Wadhia et al. 2007).

Battery of biotests is suggested to be used for precise information about the whole aquatic ecosystem (Wenzel et al. 1997; Persoone et al. 2003; Wolska et al. 2007), however some authors indicate that sufficient information might be provided also when only one of the most sensitive types of microbiotests is applied (Mankiewicz-Boczek et al. 2008).

The study aimed to estimate the phytotoxicity of the sediments in one of the Polish dam reservoirs, give the picture of spatial vriability of sediments toxicity with attempt to explain its possible cause. 


\section{Study site}

Sediment samples have been collected from the Sulejów Reservoir, located on the Pilica river (central Poland) (Fig. 1). The Reservoir is being supplied by two tributaries Pilica (82\%) and Luciąza (14\%) - rivers, which deliver only partially treated municipal sewage from three cities: Piotrków Trybunalski (78000 inhabitants), Sulejów (6332 inhabitants), Przedbórz (3786 inhabitants) (Ambrożewski 1980; Wagner and Zalewski 2000). The Reservoir (length - $15.5 \mathrm{~km}$; maximum width $-2.1 \mathrm{~km}$; surface area $-22 \mathrm{~km}^{2}$ ) is a shallow (maximum deep - $11 \mathrm{~m}$, mean depth - 3.3 $\mathrm{m})$ eutrophic reservoir with average water retention time about 30 days (Ambrożewski 1980). The reservoir has been used as drinking water source and for recreational purposes in spite of poor water quality due to cyanocterial blooms that appear every summer (Wagner and Zalewski 2000; Izydorczyk, Skowron et al. 2008).

The reservoir is periodically impacted with strong waving events, which enhance water mixing and sediments resuspension and may enhance mo-

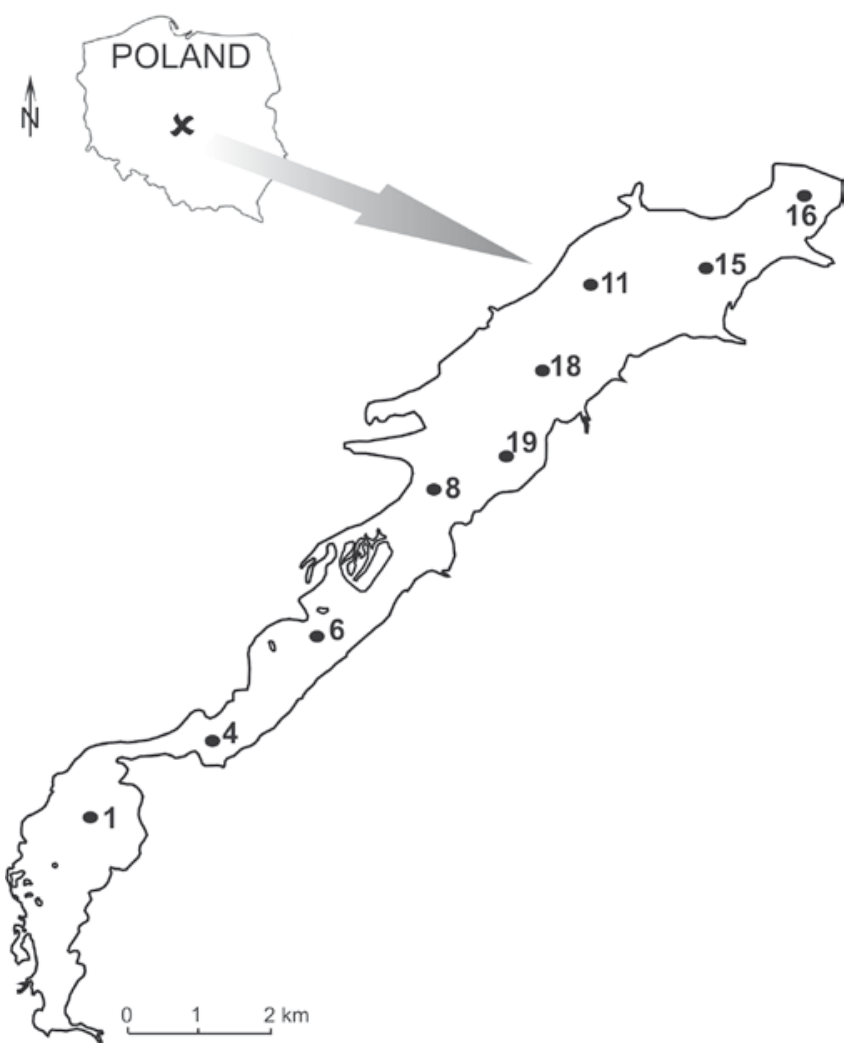

Fig. 1. Location of study site and sampling points in the Sulejów Reservoir bilization of toxic substances into water column. The reservoir has been operated since 1974 and hence a big amount of bottom sediments have accumulated in it. Contamination of sediments with heavy metals has not been confirmed (Trojanowska et al. 2007). Metals concentrations: $\mathrm{Zn}, \mathrm{Ni}, \mathrm{Pb}, \mathrm{Cd}, \mathrm{Co}, \mathrm{Fe}, \mathrm{Cr}, \mathrm{Cu}$ remain below the geochemical background (according to classification by Bojakowska and Sokołowska 1998). Metals concentration did not show significant spatial variation in sediment of the Sulejów reservoir, only slightly lower contents were recorded in the backwater part before narrowing (Trojanowska et al. 2007). The presence of other toxic substances in the sediments of the reservoir have not been reported so far.

\section{Methods}

Sediments samples were taken from 9 points covering randomly the area of the Sulejów Reservoir bed, location of the sampling stations is presented on the Fig.1.

Samples were taken using a grab sampler (Ekman-Bridge type). Samples were dried in $80^{\circ} \mathrm{C}$ and then crumbled, homogenized and sieved thru a sieve with a $2 \mathrm{~mm}$ mesh. Such prepared sample was used to perform microbiotests using a set of Phytotoxkit, which measures two kinds of early growth effects: the decrease of seed germination and the decrease of root growth in comparison to germination and root growth in a control soil (in analogy to ISO standard 112691: "Determination of the effects of pollutants on soil flora - Part 1. Method for the measurement of inhibition of root growth"). The test was made using one monocotyl (Sorghum saccharatum) and two dicotyl plants (Lepidium sativum and Sianpis alba) delivered by manufacturer. $90 \mathrm{~cm}^{3}$ of sieved sediments or refference sand was put in a lower compartment of a test plate (delivered by manufacturer) and hydrated with appropriate amount of distilled water (estimated on the basis of water holding capacity). Surface of the sediments tested was flatten and covered by paper filter. Thenafter 10 seeds of plant were put on the surface of paper filter and covered with surface platic plate. Operation was repeat for each seed for the 3 controll and the 3 sediment plates. Prepared phytotoxkit plates were incubated at $25^{\circ} \mathrm{C}$ in 3 days. After incubation pictures of the plates were made with digital camera. He pictures were thenafter analysed using IMAGETOOL 3.0 (UTHCSA, United States) software: the number of germinated seeds was counted as well as the lenght 
of rots was measured. Average values were used for final calculation of the percentage inhibition of seed germination and root growth which was made using following equation:

$$
\frac{A-B}{A} \times 100=\text { inhibition }[\%] \text {, }
$$

where: A - mean seed germination or root length in the control soil, and B - mean seed germination or root length in the test soil.

Maps of spatial diversity of sediments toxicity were made using SURFER 6.0 software, interpolation was made according to krigging method. Cluster analysis was made using STATISTICA 9.0 software, where single bond method was used to express the range of resemblance of tested sampling stations.

\section{Results}

Toxicity expressed as inhibition of seed germination has been generally lower (average calculated for all samples 31\%) than the root growth inhibition index (average calculated for all samples $72 \%$ ). The highest rate for both indicators was observed in case of L. sativum; $73 \%$ for seed germination and $92 \%$ for root growth. The lowest values of both indexes were recorded for S. alba (6\% and 59\%, respectively), while for S. saccharatum $13 \%$ of seed germination repression and $66 \%$ of root growth retardation. S. alba did not exhibited any toxic reaction in six sampling points, whereas $S$. saccharatum in four sampling points, while only two of these sampling points (No. 6 and 11) have obtained consistent results for both plant species (Fig. 2).
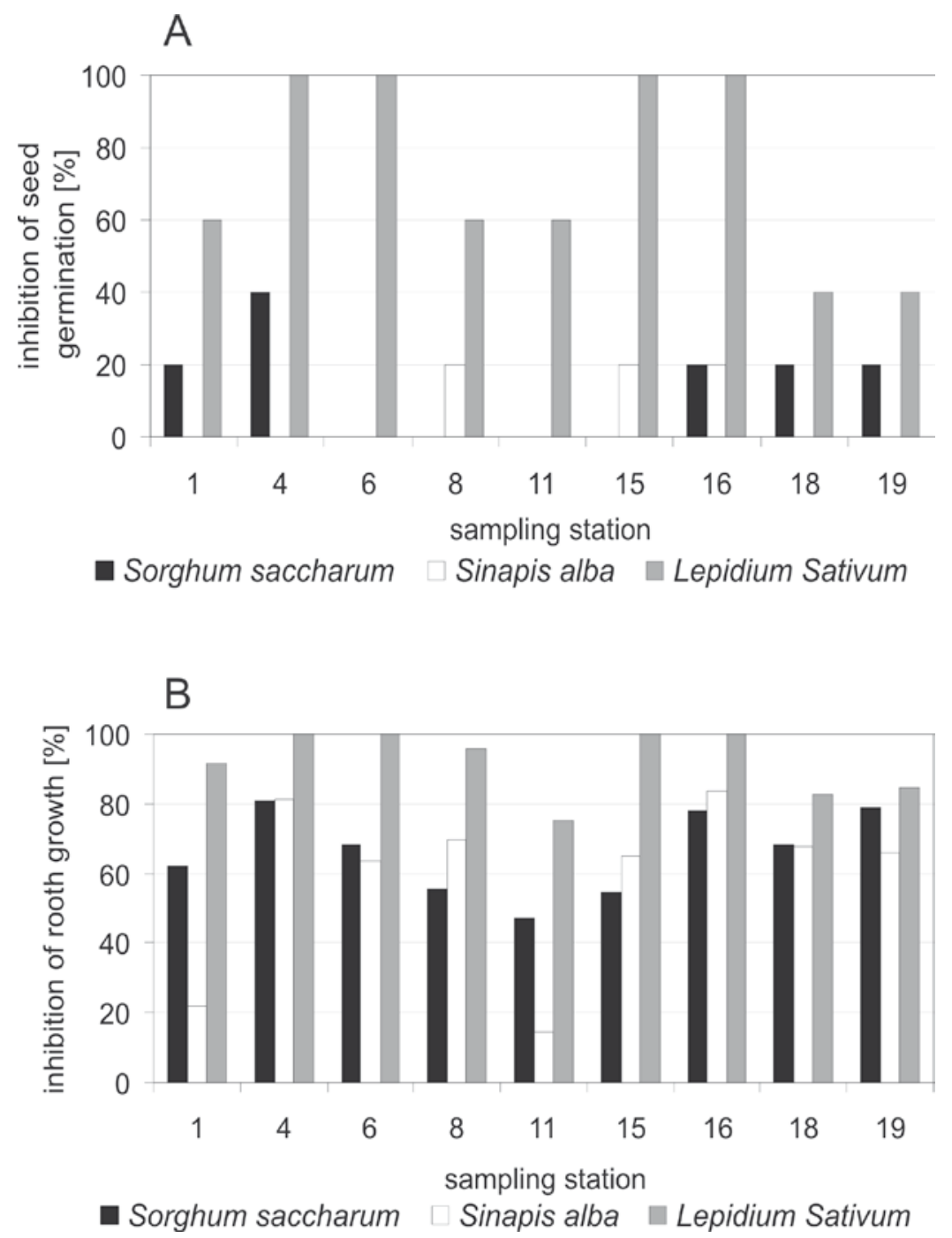

Fig. 2. Percentage inhibition of seed germination (A) and root growth (B) of Lepidium sativum, Sinapsis alba, Sorgum saccharatum caused by sediments from each sampling point 
L. sativum in all samples showed repression in case of both indexes, whither in sampling points No. 4, 6, 15, 16 achieved values of $100 \%$ inhibition of both, seed germination and root elongation (Fig. 2).

Characteristic pattern was observed in spatial variation of sediment toxicity, dividing the basin in two parts; upper and lower part of the reservoir, where the values of inhibition of both, seed germination and root growth were elevated in comparison to central part of the reservoir (Fig. 3). More sensitive root growth index designated toxically endangered areas as more extended (Fig. 3).

Sampling points (No. 4 and 16) of the highest recorded average toxicity ( $46 \%$ of seed germination repression and $87 \%$ of root growth inhibition) were located in the opposite ends of the reservoir (Fig. 3). Visible in Fig. 3 division of the reservoir into two parts resulted from lower values of toxicity indicators in its central part (stations No. 11, 18, 19).

In the sampling point No. 11 the overall lowest values of both analysed toxicity indicators have been reported $(20 \%$ repression of seed germination and
$45 \%$ of root growth inhibition). Also in the stations No. 18 and 19 the inhibition of seed germination was as low (20\%), however, the second indicator was much higher (74 and $76 \%$, respectively).

The division into upper and lower parts within the reservoir was confirmed by cluster analysis performed on the basis of the average values of both applied indicators of toxicity. The results (Fig. 4) indicated two main groups containing the sampling points of a high degree of similarity. First group includes stations located in the lower part of the reservoir, which are clustered in two subgroups (sampling points No. 15,16 , of a high toxicity and No. 18, 19 of a lower values). Second main group includes several subgroups hierarchically collecting remaining sampling stations in following order: $1,11,4,6,8$. the results of cluster analysis and the maps suggest change and differentiation of conditions along the reservoir.

Statistically significant relationship between toxicity and both, organic matter content and $\mathrm{pH}$ in the sediment have not been confirmed. However, water content in sediments showed positive correla-
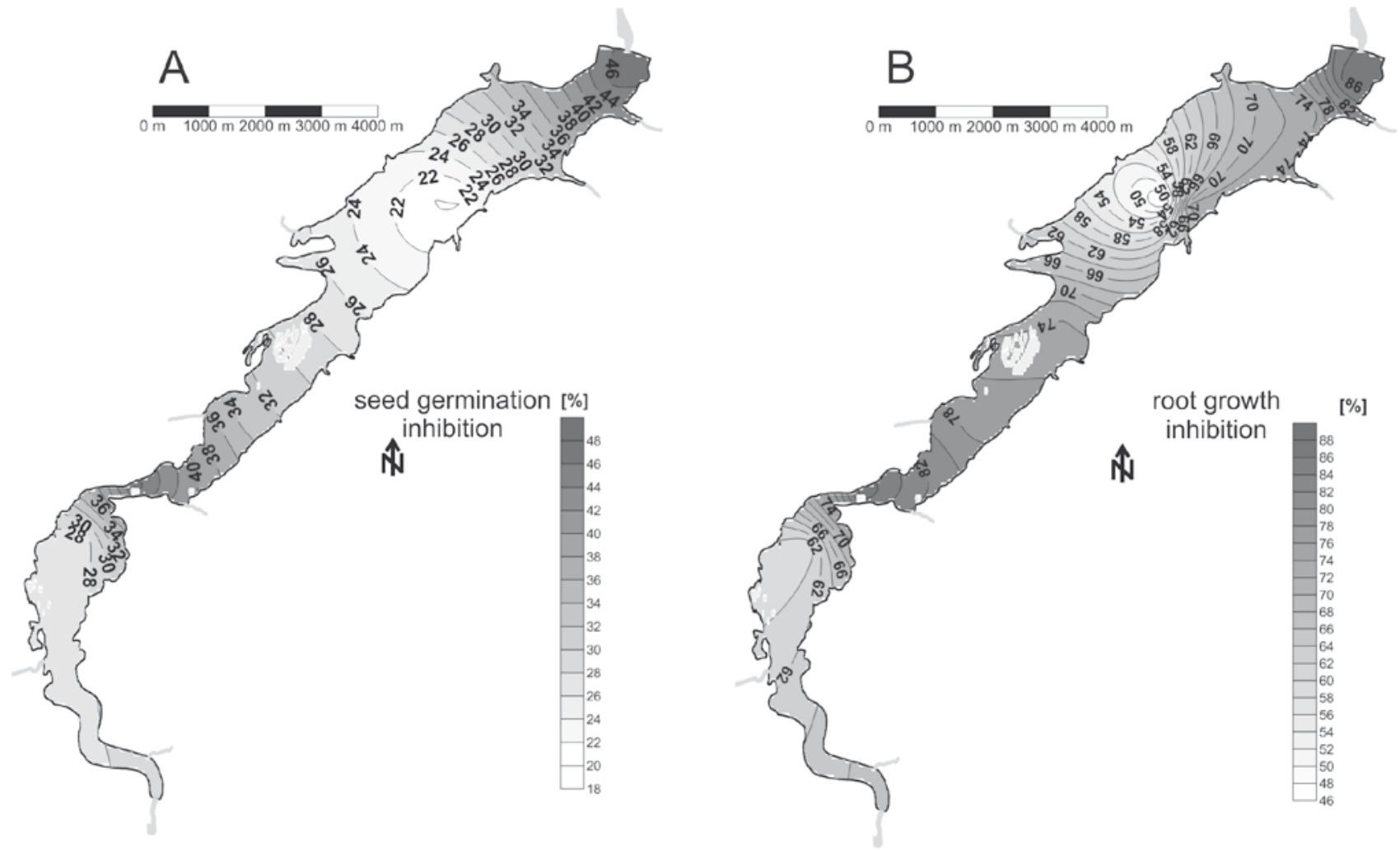

Fig. 3. Spatial diversity of toxicity of bottom sediments in the Sulejów reservoir expressed as average inhibitions of seed germination (A) and root growth (B) 


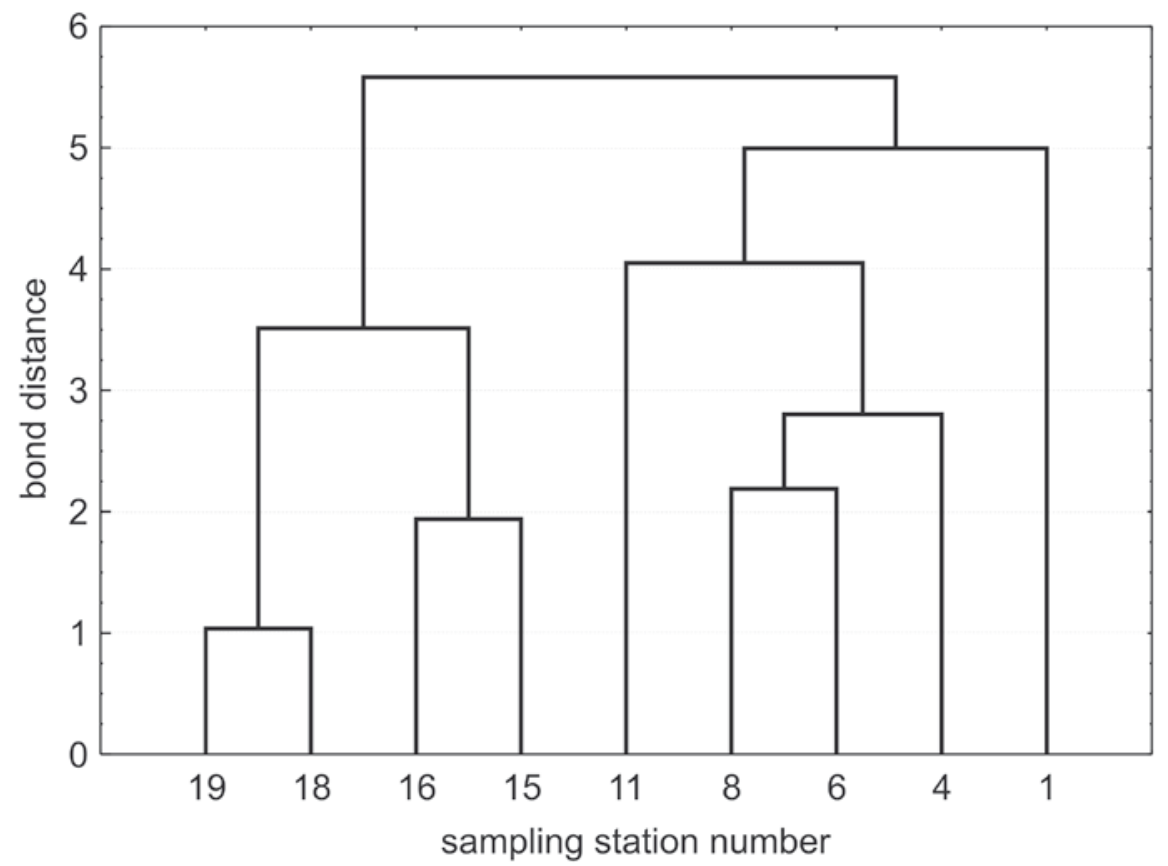

Fig. 4. Results of cluster analysis; spatial diversity of sediments toxicity in the Sulejów reservoir

tion with average root growth inhibition $(r=0.65, p<$ $0.05)$, however only in case of $S$. saccharatum the relation was statistically significant indeed $(r=0.81, p<$ $0.05)$, for other species such interdependence have not been confirmed (Fig. 5).

\section{Discussion}

Many of authors confirmed that the Phytotoxkit microbiotest is effective in identifying toxic samples contaminated with heavy metals, PAHs, pesticides (Czerniawska-Kusza et al. 2006; Wadhia and Thompson 2007; Mankiewicz-Boczek et al. 2008; Oleszczuk 2008; Sekutowski and Sadowski 2009). In the Sulejowski Reservoir all collected sediment samples have given phytotoxic response. The highest phytotoxicity was recorded in case of tests with L. sativum in both indexes; seed germination and root growth retardation. Similar observations have been reported other researchers working with sediments in dam reservoirs
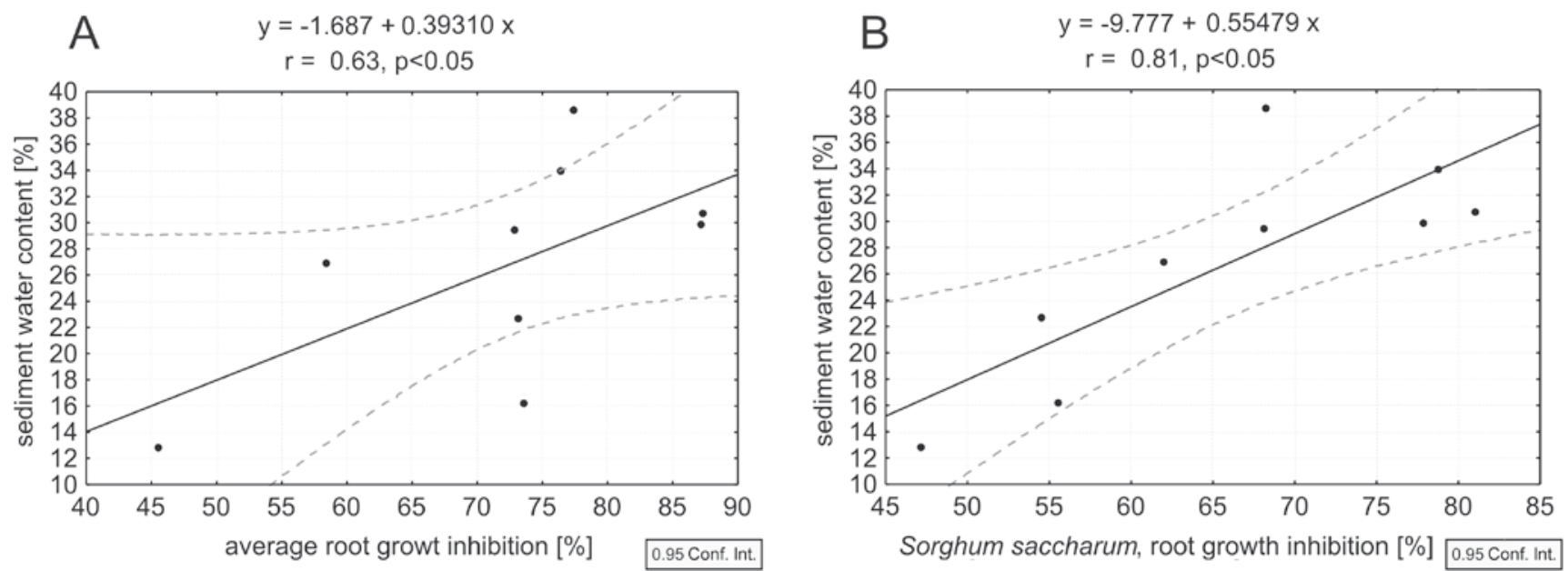

Fig. 5. Scatter plots of sediment water content and: average root growth inhibition (A); Sorgum saccharatum root growth inhibition (B) 
(Czerniawska-Kusza and Kusza 2010). MankiewiczBoczek et al. (2008) indicate as the most sensitive $S$. saccharatum. The lowest sensitivity was observed in case of S. alba, however Sekutowski and Sadowski (2009) demonstrated this plant as the most responsive in the case study of toxic effects of herbicides on higher plants.

Tests made with L. sativum and S. saccharatum gave quite comparable results for both; inhibition of seed germination and root growth retardation, which relevance was confirmed by statistically significant Pearson correlation coefficients $r=0.80, \mathrm{p}<0.05$ and $r=0.78, p<0.05$, respectively. In case of $S$. alba the interrelationship between both studied phytotoxicity indexes was statistically insignificant $(r=0.41, p<0.05)$, and was probably the least reliable indicator.

If comparing two indicators of ecotoxicity, based on: seed germination and growth of roots, it appears that the results given by each of them are sometimes distinct. Inhibition of seeds germination often indicate lower toxicity than roots growth index. Root growth inhibition is more sensitive than the seed germination retardation.

These observations have been confirmed by Oleszczuk (2008) and Baran et al. (2008) who pointed that the rate of inhibition of seed germination is highly sensitive for heavy metals, certain polymers and petroleum. But in many cases seeds sprouting is observed even despite the presence of these substances in the environment. However, later they express phytotoxicity as a roots growth inhibition (Oleszczuk 2009).

The highest toxicity of sediments expressed by both: seed germination and roots growth was recorded in the central basin of the Sulejów Reservoir just behind its narrowing, that separates back water part from the main basin, and in lower part of the reservoir near the dam. Such a spatial distribution of toxic sediments in the reservoir can be connected with the shape of the reservoir bed and hydrological conditions. Narrowing behind the backwater part of the reservoir due to slowed down water flow creates sedimentation area for organic particulate matter, suspended colloids etc. and associated contaminants transported by tributaries (Straskraba 1999). Association of heavy metals and other pollutants with the fine fraction of organic matter or clay in sediments has been confirmed by many authors (Dojlido and Taboryska 1991; Bojakowska, Gliwicz et al. 2000; Bojakowska, Sokołowska et al. 2000; Ciemniak et al. 2005; Gierszewski 2008). Howev- er in the case of this reservoir exceedances of natural concentrations of heavy metals, PAHs and pesticides have not been reported so far.

Elevated phytotoxicity of sediments in the lower part of the Sulejów reservoir is probably connected with toxic cyanobacterial blooms which occur intensively every summer in this area (Izydorczyk, Skowron et al. 2008). Dead cyanobacterial cells drop down to the bottom of the reservoir and during lysis the cells release cyanotoxins, which can remain chemically active for months as dissolved or associated with fine particulate organic matter and clay (Morris et al. 2000; Zakaria et al. 2007).

Czerniawska-Kusza et al. (2006) proved significant role of sediment organic matter content and grain-size distribution in sediment contamination and higher plant responses to contaminated samples (Czerniawska-Kusza et al. 2006). However this interactions have not been confirmed in our studies. Lack of positive correlation of phytotoxicity with organic matter and positive relationship of roots elongation with water content in sediments suggest stronger effect of substances soluble in water and negligible impact of particulate organic contaminants. This also could support the explanation of phytotoxicity caused by microcystins, which as a polar compound is easily soluble in water. Wörmer et al. (2010) estimated that during a Microcystis dominated bloom, around 4.5\% microcystins from water column may be involved in sedimentation, which is a major mechanism of cyanotoxins delivery to sediments. At oxic or microaerophilic $\left(<2 \% \mathrm{O}_{2}\right)$ conditions, microcystin decomposition takes more than 7 weeks (Holst et al. 2003). High concentrations of microcistins during cyanobacterial blooms in the Sulejowski reservoir was confirmed many times in last decade (Izydorczyk, Jurczak et al. 2008; Izydorczyk et al. 2009).

Cluster analysis confirmed diversification of spatial conditions along the reservoir: upper and lower part with the highest toxicity recorded in opposite ends of the reservoir.

Lack of fluent phytotoxicity variation along the reservoir, or at least along the main stream or one of the shores, may point to two different sources of origin of toxicity in sediments. The upper part can be supplied in contaminants from the reservoir catchment by tributaries, while in the lower part toxicants can be produced in situ, such as cyanotoxins. However, confirmation or exclusion of this thesis requires further study. 


\section{Conclusions}

The overall studied sediment samples taken from the Sulejow Reservoir gave phytotoxic response. However, its spatial variation suggest different source and character of toxicants in the upper and lower parts of the reservoir.

Tested plants gave different response to sediment samples, with decreasing sensitivity gradient: $L$. sativum, S. saccharatum, S. alba.

Lack of positive correlation of phytotoxicity with organic matter and positive relationship of roots elongation with water content in sediments suggest the strongest effect of substances soluble in water, including cyanotoxins importance, and negligible impact of contaminants in form of particular organic compounds.

\section{Acknowledgments}

This studies were supported by grant of Polish Ministry of Science and Higher Education No.: R1205602. I would like to acknowledge dr Marta Kurasiewicz, dr Piotr Jezierski, dr Wojciech Drzewicki, Janusz Krajniak and students: Radosław Drynda, Łukasz Pleśniak for their substantial help in field works as well as Polish Fishery Board, Branch in Piotrków Trybunalski for possibility to use their boat during sampling campaign.

\section{References}

Ambrożewski Z., 1980, Monografia Zbiornika Sulejowskiego (Monograph of the Sulejow Reservoir), WKiL, Warszawa, p. 84 (in Polish).

Bojakowska I., Sokołowska G., 1998, Geochemiczne klasy czystości osadów wodnych (Geochemical class of sediments cleanliness), Prz. Geol. 46: 49-53 (in Polish).

Bojakowska I., Gliwicz T., Sokołowska G., Strzelecki R., Wołkowicz S., 2000, Pierwiastki śladowe i promieniotwórcze w osadach zbiornika włocławskiego (Radioactive and trace elements in sediment of the Włocławek Reservoir), Prz. Geol. 48: 831-837 (in Polish).

Bojakowska I., Sokołowska G., Strzelecki R., 2000, Trwałe zanieczyszczenia organiczne - wielopierścieniowe węglowodory aromatyczne, polichlorowane bifenyle i pestycydy chloroorganiczne - w osadach zbiornika zaporowego Włocławek (Persistent organic pollutants - polycyclic aromatic hydrocarbons, polychlorinated biphenyls and pesticides chlorine - in the Włocławek dam reservoir sediments), Prz. Geol. 48: 837-843 (in Polish).
Bojakowska I., Gliwicz T., 2003, Wyniki geochemicznych badań osadów wodnych polski w latach 2000-2002 (The results of geochemical studies of Polish sediments from 2000 to 2002), Biblioteka Monitoringu Środowiska, IOŚ, Warszawa, p. 120 (in Polish).

Ciemniak A., Gurwin J., Protasowicki M., Skowronek A., Wieczorek P., Witczak A., 2005, Badania zanieczyszczeń osadów dennych jeziora Turawskiego (The study of pollution of Turawskie Lake bottom sediments), [in:] Mat. III Konf. Zasoby wodne Triasu Opolskiego i Ekologia Jezior Turawskich (Proc. III Conf. Water Resources of Opole Triassic and Ecology of Turawskie Lakes), Wyd. NOT Opole, Opole: 239-240 (in Polish).

Czerniawska-Kusza I., Ciesielczyk T., Kusza G., Cichoń A., 2006, Comparison of the Phytotoxkit microbiotest and chemical variables for toxicity evaluation of sediments, Environ. Toxicol. 21: 367-372.

Czerniawska-Kusza I, Kusza G., 2010, The potential of the Phytotoxkit microbiotest for hazard evaluation of sediments in eutrophic freshwater ecosystems, Environ. Monit. Assess. [in press], doi: 10.1007/s10661-010-1722-y.

Dojlido J.R., Taboryska B., 1991, Exchange of heavy metals between sediment and water in the Wloclawek Reservoir on the Vistula River, [in:] N.E. Peters, D.E. Walling (eds) Sediment and Stream Water Quality in a Changing Environment: Trends and Explanation (Proc. Vienna Symp., August 1991), IAHS Publ. 203, IAHS Press, Wallingford: $317-320$.

Gierszewski P., 2008, Koncentracja metali ciężkich w osadach zbiornika włocławskiego jako wskaźnik hydrodynamicznych depozycji (The concentration of heavy metals in the Włocławek reservoir sediments as an indicator of hydrodynamic deposition), Landf. Analys. 9: 79-82 (in Polish).Håkanson L., Jansson M., 1983, Principles of lake sediemntology, Springer-Verlag, BerlinHeidelberg-New York-Tokyo, p. 316.

Holst T., Jørgensen N.O.G., Jørgensen C., Johansen A., 2003, Degradation of microcystin in sediments at oxic and anoxic, denitrifying conditions, Water Res. 37: 4748-4760.

Izydorczyk K., Skowron A., Wojtal A., Jurczak T., 2008, The Stream Inlet to a Shallow Bay of a Drinking Water Reservoir, a 'Hot-Spot' for Microcystis Blooms Initiation, Int. Rev. Hydrobiol. 93: 257-268.

Izydorczyk K., Jurczak T., Wojtal-Frankiewicz A., Skowron A., Mankiewicz-Boczek J., Tarczyńska M., 2008, Influence of abiotic and biotic factors on microcystin content in Microcystis aeruginosa cells in a eutrophic temperate reservoir, J. Phycol. 30: 393-400.

Izydorczyk K., Carpentier C., Mrówczyński J., Wagenvoort A., Jurczak T., Tarczyńska M., 2009, Establishment of an Alert Level Framework for cyanobacteria in drinking water resources by using the Algae Online Analyser for monitoring cyanobacterial chlorophyll $a$, Water Res. 43: 989-996. 
Kaza M., Mankiewicz-Boczek J., Izydorczyk K., Sawicki J., 2007, Toxicity assessment of water samples from rivers in Central Poland using a battery of microbiotests - a pilot study, Pol. J. Environ. Stud. 16: 81-89.

Majstereka I., Sicinska P., Tarczynska M., Zalewski M., Walter Z., 2004, Toxicity of microcystin from cyanobacteria growing in a source of drinking water, Comp. Biochem. Phys. C 139: 175-179.

Mankiewicz-Boczek J., Nałęcz-Jawecki G., Drobniewska A., Kaza M., Sumorok B., Izydorczyk K., Zalewski M., Sawicki J., 2008, Application of a microbiotests battery for complete toxicity assessment of rivers, Ecotox. Environ. Saf. 71: 830-836.

Latif M., Licek E., 2004, Toxicity assessment of wastewaters, river waters, and sediments in Austria using cost-effective microbiotests, Environ. Toxicol.19: 302-309.

Morris R.J., Williams D.E., Luu H.A., Holmes C.F., Andersen R.J., Calvert S.E., 2000, The adsorption of MCYST-LR by natural clay particles, Toxicon 38: 303-308.

Phytotoxkit, 2008, Seed Germination and early growth microbiotest with higher plants. Standard operational procedure, Microbiotests Inc. Nazareth, Belgium, p. 24.

Oleszczuk P., 2008. Phytotoxicity of municipal sewage sludge composts related to physico-chemical properties, PAHs and heavy metals, Ecotox. Environ. Safe. 69: 496505.

Oleszczuk P., 2009, Toxicity of Light Soil Fertilized by Sewage Sludge or Compost in Relation to PAHs Content, Water Air Soil Pollut. [in press], doi: 10.1007/s11270-0090257-8.
Sekutowski T., Sadowski J., 2009, Phytotoxkit ${ }^{\mathrm{TM}}$ microbiotest used in detecting herbicide residue in soil, Environ. Prot. Eng. 35: 105-110.

Straskraba M., 1999, Retention time as a key variable of reservoir limnology, [in:] J.G. Tundisi, M. Straskraba (eds) Theoretical Reservoir Ecology and its Applications, Backhuys Publ., Leiden: 385- 410.

Trojanowska A., Polański K., Zawadzka A., Izydorczyk K., 2007, Przestrzenne zróżnicowanie zawartości wybranych pierwiastków, w tym metali ciężkich w osadach Zbiornika Sulejowskiego przed i po wystąpieniu zakwitu sinicowego (Spatial differences in the content of selected elements, including heavy metals in sediments of the Sulejow Reservoir before and after the cyanobacterial bloom), [in:] K. Gwoździński (ed) Bory Tucholskie i inne obszary leśne: ochrona, monitoring, edukacja ( $\mathrm{Tu}$ cholskie Forest and other forest areas. Protection, monitoring, education), Wyd. UŁ, Łódź: 361-370 (in Polish).

Zakaria A.M., El-Sharouny H.M., Ali W.S., 2007, Microcystin Concentrations in the Nile River Sediments and Removal of Microcystin-LR by Sediments During Batch Experiments, Arch. Environ. Contam. Toxicol. 52: 489495.

Wadhia K., Thompson K.C., 2007, Low-cost ecotoxicity testing of environmental samples using microbiotests for potential implementation of the Water Framework Directive, Trends Anal. Chem. 26: 300-307.

Wörmer L., Cirés S., Quesada A., 2010, Importance of natural sedimentation in the fate of microcystins, Chemosphere [in press], doi:10.1016/j.chemosphere.2010.11.024. 